\title{
Science behind the scenes
}

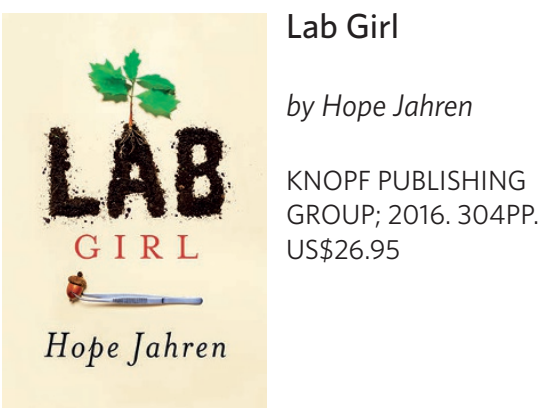

n her best-selling memoir Lab Girl, paleobiologist Hope Jahren tells many stories: how a seed puts down its first roots, two friends take on impossible tasks with a shoestring budget, and a girl becomes a world-class scientist.

Scientists are often storytellers; every chemist I know has at least one 'near miss' from the lab, and the more potentially dangerous or destructive the incident, the more often it is told. Stories like these always seem to begin "Did I tell you about the time...?" I recall the time a newbie filled a lab with smoke from an overheating vacuum pump and the time a labmate accidentally condensed a large quantity of oxygen in a cold trap. My own such story involves a faulty fumehood sash and a lungful of gaseous ammonia I inhaled while the product I had struggled to make sprayed out of the flask and across the lab floor.

Perhaps you share stories of less hazardous scenarios. You may remember when a freezer thawed and its carefully preserved contents had to be thrown away, or when you left your poster at airport security on your way to a conference. At the time we often feel like incompetents, but later we swap our stories, laugh at our luck, cringe at our lack of forethought and roll our eyes at the mistakes made by people who should know better.

We also share stories of success: the first time a difficult experiment worked, the relief of having a paper accepted, and the moments when science brought us joy and wonder. These stories tend not to generate the same commiserating laughs as the lab follies, but they are the ones we turn to when we want to encourage and inspire.

Lab Girl chronicles Jahren's adventures in persistence; it tells of failures overcome, long days without rest, hardships endured, and the buoying support of her friend and research partner, Bill. She recalls dreaming up ways to do "wonderful and previously impossible things," and the thrill of discovering a new fact that no-one has ever known before. She tells near miss stories too: the night of her graduation, she narrowly escaped a face full of shards when the carbon-dioxide-filled tubes she had been making abruptly exploded. Short explanations of plant biology alternate with longer chapters about Jahren's life, and as the seedling turns its leaves toward the sun, the child grows into the woman, the novice becomes an expert.

\section{Lab Girl chronicles Jahren's}

adventures in persistence; it tells of failures overcome, long days without rest, hardships endured, and the buoying support of her friend and research partner, Bill.

Bill features in nearly every story, providing Jahren with moral support, comic relief, and an incredible ability to fashion specialized equipment out of cast-offs, hand-me-downs and hardware store odds-and-ends. From the early years in Georgia, at times homeless and hungry, to the recent successes in Hawaii, Bill has helped transform the Jahren lab from a dream and a dreary basement into a sophisticated greenhouse and laboratory.

Life as a professional scientist is rough. There is hardly enough funding to go around - and there aren't enough jobs. But being a scientist costs nothing; you just have to ask questions and make observations. Jahren writes about both sides of science: the struggles involved in building a career, and the sense of awe and wonder that draws so many of us into our respective fields. She does not promise that the path of a scientist is easy, but she does not entirely warn us away, either. Growth will be hard, the resources scarce, the environment often inhospitable, yet it is possible to thrive.
Lab Girl resonates with me. We began our careers twenty years apart in different fields with different approaches, and yet many of Jahren's stories sound familiar. I, too, came from a small town and moved away from home to learn that "the world is mostly populated by strangers". I, too, have encountered creepy male colleagues and patronizing attitudes. I, too, faced my own first class uncertain that I fit the professor mould. I, too, have relied on a friend to walk me away from the precipice of worries that I'll never get a grant or I am not smart enough for my chosen career. I have had failures and successes, and I've marvelled at the incredible beauty of science. Like the seeds in a forest "waiting in the soil, alive and fervently wishing to be," I have been waiting and wishing, daring to extend my first root and unfurl my first leaf, hoping that I am resilient enough to weather the harsh winters of science. I, too, am a lab girl.

Jahren picks her words deliberately. She simplifies descriptions of scientific instruments, concepts and phenomena to make them approachable. For example, her explanation of mass spectrometry lacks many technical details, but it conveys the basic principles in a way that novices can understand and appreciate without feeling condescending. At the same time, her anecdotes are delightful and highly quotable. I recognize a poet in her prose. When describing an early job at a hospital, she did not simply mix medicines; she "injected twenty milliliters of salvation into a bag of tears". You could take a sentence from nearly any page and hang it on the wall as words to learn from or live by.

Even if it weren't already a bestseller, Lab Girl would be important. It's a behind-the-scenes view of how scientists are made, how actual science gets done, and what stories aren't told in the final published manuscript. Lab Girl leaves me wanting more stories like these. We need a diversity of voices in science, and Hope Jahren's - though humorous, engaging and insightful - is just one.

\section{REVIEWED BY BETH L. HAAS}

Beth L. Haas is in the Department of Chemistry and Biochemistry, Misericordia University, Dallas, Pennsylvania 18612, USA. 